\title{
O SAGRADO FEMININO NA PRIMAVERA BÍBLICA
}

\author{
Lidice Meyer Pinto Ribeiro*
}

\section{RESUMO}

A relação entre a mulher e a fertilidade transparece nos rituais de primavera desde os tempos imemoriais. Através de uma leitura atenta da Bíblia sob o enfoque da antropologia bíblica, percebe-se a constante presença feminina nos eventos relacionados à primavera no Antigo e Novo Testamentos bem como sua associação simbólica com arquétipos da Deusa-mãe e das deusas Inanna/Ishtar, Ísis e Perséfone. Observa-se também a constância da face feminina de Deus, ruach, e de repetições tríplices que apontam para representações da totalidade do gênero feminino. A presença da primavera se destaca na condução da trama bíblica desde a formação do povo de Israel à chegada e sacrifício do Messias bem como na promessa de sua segunda vinda.

Palavras-chave: Sagrado feminino. Antropologia bíblica. Mulheres na Bíblia. Ruach. Deusas.

\section{THE SACRED FEMININE IN BIBLICAL SPRING}

\section{ABSTRACT}

The relationship between women and fertility has been reflected from immemorial times on spring rituals. Through an attentive reading of the Bible with a focus on biblical anthropology, one can perceive the constant female presence in spring-related events in the Old and New Testaments as well as their symbolic association with archetypes of the Mother Goddess and goddesses Inanna / Ishtar, Isis and Persephone. It is also observed the constancy of the feminine face of God, ruach, and triple repetitions that point to representations of the totality of the feminine gender. The presence of spring stands out

* Doutora em Antropologia Social pela Universidade de São Paulo (USP), Pós doutora em Antropologia e História pela Universidade de São Paulo (USP), Pós doutoranda em Estudos de Globalização pela Universidade Aberta de Lisboa, Docente convidada no Programa de Mestrado em Ciência das Religiões da Universidade Lusófona de Humanidades e Tecnologias em Lisboa, Portugal. 
in the conduct of the biblical plot from the formation of the people of Israel to the arrival and sacrifice of the Messiah as well as in the promise of his second coming.

Keywords: Sacred feminine. Biblical anthropology. Women in the Bible. Ruach. Goddess.

\section{LO SAGRADO FEMENINO EN LA PRIMAVERA BÍBLICA}

\section{RESUMEN}

La relación entre la mujer y la fertilidad se ha reflejado en los rituales primaverales desde tiempos inmemoriales. A través de una lectura atenta de la Biblia con un enfoque en la antropología bíblica, se puede percibir la presencia femenina constante en los eventos relacionados con la primavera en el Antiguo y Nuevo Testamento, así como su asociación simbólica con los arquetipos de la Diosa madre y las diosas Inanna / Ishtar, Isis y Perséfone. También se observa la constancia del rostro femenino de Dios, ruach y triples repeticiones que apuntan a representaciones de la totalidad del género femenino. La presencia de la primavera se destaca en la conducción de la trama bíblica desde la formación del pueblo de Israel hasta la llegada y sacrificio del Mesías, así como en la promesa de su segunda venida.

Palabras clave: Sagrado femenino. Antropología bíblica. Mujeres en la Biblia. Ruach. Diosas.

\section{INTRODUÇÃO}

Desde os tempos imemoriais a mulher e a natureza foram associadas pela sua fertilidade. A mulher era percebida como um ser detentor de poderes especiais capazes de gerar a vida, nutrir e preservar. A observação da relação entre os ciclos femininos com os ciclos dos animais, da vegetação e da Lua fez com que aquela fosse associada à terra, sendo incorporada nas crenças da Deusa-mãe ou Grande-deusa. Tudo nasce dela e tudo volta a ela após a morte. É a responsável pela fertilidade dos campos e dos animais, mas também é força destruidora quando castiga através de seus elementos. Exige tributos e oferendas para manter o ciclo constante de nascimento, crescimento, morte e renascimento. Erich Neumann (2011) afirma que um de seus traços fundamentais é ser coincidentia oppositorum, sendo reverenciada com dupla personalidade: como mãe bondosa e como mãe terrível - útero 
e túmulo da humanidade, exercendo o poder ambíguo de promover tanto a vida como a morte.

As estatuetas pré-históricas que receberam a designação de vênus remontam a mais de 35 milênios como uma forte evidência arqueológica de um período em que os povos veneravam a sacralidade feminina na Deusa-mãe. Sua distribuição geográfica abrange toda a Europa, África e Oriente-médio, sendo um dos mais antigos símbolos arquetípicos do feminino (Marija GIMBUTAS,1974). Embora não se possa afirmar como estas estatuetas eram utilizadas de forma ritual, Mircea Eliade (2010, p. 32) destaca que elas "representam de alguma forma a sacralidade feminina e, consequentemente, os poderes mágico-religiosos das deusas". Podemos, portanto, afirmar que desde os seus primórdios a humanidade já demonstrava uma veneração especial pela figura feminina e pelo que esta representava. "Uma religião e uma visão de mundo que refletiam a importância da mulher como fonte de fertilidade e preservação da vida." (John BOWKER, 2002, p. 32) Assim é que, desde os assentamentos do período neolítico, os rituais de fertilidade tornaram-se fundamentais para garantir os ciclos de nascimento-morte-regeneração. Festivais relacionados aos ciclos lunares associavam os rituais de fertilidade às deusas e ao feminino.

Há milênios que a primavera tem sido anunciada pela via do feminino. Primavera: passagem da morte para a vida, ressurreição, renascimento, fertilidade. Enfim, vida! No mundo antigo no hemisfério norte a páscoa coincide com a chegada da primavera e, com ela, ocorre o retorno da vida aos campos e plantações. Das festas e rituais ligados à fertilidade surgiram símbolos imemoriais que sobrevivem mesmo na pós-modernidade: flores, ovos e coelhos.

\section{O SAGRADO FEMININO E A PRIMAVERA NA MITOLOGIA ANTIGA}

A fertilidade da mulher sempre foi associada à fertilidade da natureza e tornou-a parte integrante e essencial nos rituais de primavera. Os antigos observavam as transformações do inverno ao verão e as explicavam através de suas crenças religiosas. As histórias de Inanna/ Ishtar, Isis e Perséfone são exemplos de como a mitologia antiga relacionava a força feminina com o retorno à vida na primavera. Todas elas são deusas ligadas ao submundo e à ressurreição da vida. 
Para os Mesopotâmios a chegada da primavera estava relacionada ao casamento entre a deusa do amor e da fertilidade Inanna com o pastor Dumuzi. Os Acádios e Sumérios a chamavam Innana de Ishtar (Jeremias 44. 17-18) e os Cananeus, de Astarte (Juízes 2.13, 10.6; 1 Samuel 31.10; 1 Reis 11.5). Dumuzi, por sua vez, foi renomeado como Tamuz pelos Acádios, Sumérios e Cananeus. Segundo o registro conhecido como Enuma Elish (Alexander HEIDEL, 1972), após uma tentativa fracassada de assumir o domínio do mundo subterrâneo, reino de sua irmã Erenshkigal, Inanna foi despida de seu poder e aprisionada por três dias como morta. Seu pai Enlil conseguiu trazê-la de volta à vida e Erenshkigal permitiu que Inanna regressasse ao mundo superior desde que lhe enviasse um substituto. Como consequência do tempo em que Inanna e Dumuzi ficaram separados, a terra e os animais perderam sua fertilidade. Ao chegar ao mundo superior, Inanna encontrou um mundo árido onde reinava a fome e a secura. Chegando ao palácio, Innana descobriu que Dumuzi aproveitou-se de sua ausência para festejar e esbanjar as riquezas, comendo e regalando-se, insensível à fome que reinava na terra. Irada, Inanna condenou Dumuzi a substituí-la na prisão do submundo junto a Erenshkigal. Todo os anos a partir de então Dumuzi vive seis meses no submundo e seis meses no mundo superior, quando é substituído por sua irmã, cunhada de Inanna, na prisão. Os seis meses em que o casal permanece separado equivalem ao outono/inverno, período de escuridão, frio e infertilidade e os seis meses em que estão juntos equivalem à primavera e ao verão, assegurando assim a continuidade do ciclo da natureza.

Dentre os Egípcios era o casamento de Isis e Osíris que mantinha a ordem das estações do ano. Ísis, a deusa da fertilidade e da maternidade é irmã e esposa de Osíris, deus da vegetação e da vida. Seth, o deus do submundo é irmão e esposo de Neftis, associada às terras secas e desérticas. O equilíbrio entre os dois casais é o que garantia a ordem e a continuidade do ciclo da natureza. Este equilíbrio é destruído por uma relação extraconjugal de Osíris com Neftis que provocou a ira de Seth levando-o a assassinar Osíris. A desordem se instala e a vida corre sério risco de ser descontinuada. Segundo Plutarco (2006), Seth retalhou o corpo de Osíris em 14 pedaços e os espalhou pelos quatro cantos do 
mundo. Ísis sai em busca de seu amado recolhendo todas as partes ${ }^{1}$ e, na forma de um pássaro, sobrevoa o corpo reconstituído de Osíris sendo por ele fecundada. É assim que Ísis conseguirá engravidar de seu esposo morto, dando à luz a Hórus, o deus celestial. Para proteger Hórus de Seth, Ísis o esconde em um cesto em meio aos juncos na beira do Nilo. Hórus vingará seu pai saindo vitorioso em uma luta contra Seth, após a qual descerá ao país dos mortos trazendo Osíris ressuscitado como "pessoa espiritual" e energia vital. De volta ao mundo superior, Osíris reina com Ísis, assegurando o retorno da fertilidade vegetal e de todas as formas de reprodução através do ciclo das cheias do rio Nilo.

As deusas Deméter e Perséfone serão as que, entre os gregos, desempenharão a função primordial de manter a fertilidade dos campos. Seu mito foi registrado por Hesíodo (2013) no Hino a Deméter. Deméter é a deusa-mãe-terra, irmã e esposa de Zeus e mãe de Perséfone, deusa ligada às ervas, flores e frutos. Perséfone é cortejada por vários deuses, mas principalmente por Hermes, deus relacionado à fertilidade dos rebanhos. Apaixonado por Perséfone, Hades, o deus dos mortos, a sequestra e a leva para o seu reino no submundo. Deméter fica inconsolável com a perda da filha e a terra se torna estéril e sem vida. Quando descobre o que aconteceu, Deméter junto com Hermes vai buscar Perséfone no submundo. Hades a devolve, mas antes lhe faz ingerir seis sementes de romã para garantir que Perséfone retornasse sempre ao submundo. A partir de então Perséfone se dividirá entre o amor de Hermes e de Hades, permanecendo metade do ano com cada um. Isso manterá o ritmo das estações do ano e do ciclo regenerativo da terra. Enquanto Perséfone está com Hades, a terra entra no período do descanso do outono-inverno, e na primavera-verão, Perséfone sobe ao Olimpo para, junto com Hermes, restituir a fertilidade aos campos e aos rebanhos.

\section{O SAGRADO FEMININO E A PRIMAVERA NO ISRAEL ANTIGO}

O povo de Israel não ficou imune aos mitos dos povos com os quais conviveu. Os diversos períodos no Egito bem como as constantes relações comerciais e conjugais com os povos egípcios, mesopotâmicos, sumérios, acádios e cananeus deixaram suas marcas na cultura e

Isis teria recuperado 13 partes do corpo de Osíris, com exceção do órgão sexual, que havia sido engolido por um peixe (PLUTARCO apud Mircea ELIADE, 2010, p. 102). 
na religião israelita. As crenças relativas às deusas e à fertilidade do solo e dos rebanhos faziam parte do cotidiano popular deste povo em formação. A pesquisa arqueológica recente (Raz KLETTER, Irit ZIFFER, Wolfgang ZWICKEL, 2015) tem cada vez mais atestado a existência de pequenos santuários erigidos pelo povo para cultos populares fora dos grandes centros de culto oficial. Um registro no livro de Ezequiel deixa claro que o culto a Dumuzi/Tamuz era conhecido e praticado por alguns israelitas após o cativeiro babilônico (Ezequiel 8.14). Como parte do culto, ao final do verão as mulheres se reuniam para lamentar a ausência de Tamuz e invocar seu retorno para a chegada da primavera. Até os dias de hoje, no calendário judaico, a segunda quinzena de junho e a primeira quinzena de julho são denominados mês de Tamuz. O livro de Daniel se refere a Tamuz como sendo o "deus querido das mulheres" (Daniel 11.37) e Isaías registra o plantio de ervas aromáticas em honra a Tamuz (Isaías 17.10). Sendo um povo onde a agricultura e o pastoreio eram as práticas econômicas basilares, tudo o que se relacionava à fertilidade passava a ser primordial no cotidiano e na religiosidade. A natureza era compreendida pelos antigos israelitas como um ciclo de morte e renascimento e a primavera marcava não só a ressurreição da vida, como também as celebrações do ano novo.

O início do ano, marcado pelo mês de Abibe, de Nissan ou das espigas coincidia com a chegada da primavera (março-abril) e finalizava com as chuvas de verão (Tiago 5.7). A instituição do pessach judaico marcou ainda mais este período que já era festivo. Para a memória e celebração da passagem da morte da escravidão no Egito para a vida na liberdade rumo à terra prometida, foram instituídas as duas festas da primavera judaica: pães asmos e das primícias. (Êxodo 13.4; 23.15; Levíticos 23). A primavera é retratada na Bíblia como um período com chuvas amenas ou serôdias (Deuteronômio 11.14; Jó 29.23; Provérbios 16.15; Jeremias 3.3, 5.24; Joel 2.23) em que os campos brotavam e produziam (Cantares 2.11; Amós 7.1; Zacarias 10.1) e a fertilidade era presente até mesmo onde menos esperada (Gênesis 18.14). Por ser um período com temperatura agradável era também o momento propício para as batalhas (2 Samuel 11.1; 1 Reis 20.26; 2 Reis 13.20; 1 Crônicas 20.1; 2 Crônicas 24.23, 36.10). 
Fazendo uma leitura mais atenta à Bíblia podemos perceber como a presença feminina é marcante nas narrativas que envolvem a primavera e a páscoa. A comemoração do pessach rememora o êxodo do Egito, onde por cerca de 430 anos o povo em formação padeceu na escravidão. 0 resgate do povo foi realizado através de um homem, Moisés, mas a vida deste líder foi preservada pela obra de três mulheres: Joquebede, Miriã e a filha do Faraó (Êxodo 2.1-10). Tendo vivido tanto tempo no Egito é de se esperar que o povo de Israel estivesse familiarizado com o mito de Ísis e Osíris. Assim é que podemos perceber, na história do resgate do menino Moisés das águas do Rio Nilo, um claro paralelo com o mito referente ao nascimento e preservação de Hórus. Segundo o mito egípcio, quando Seth descobre o nascimento de Hórus, que poderia vir a reclamar o seu direito ao trono do falecido pai, Osíris, decide matar o menino. Ísis para proteger Hórus, faz um cesto onde o coloca escondendo-o nas moitas de junco no rio Nilo. É lá que Ísis amamenta Hórus e lhe pede que defenda o povo egípcio de Seth, o deus do deserto e assassino de seu pai, Osíris. Na história de Moisés, relatada no livro do Êxodo, Joquebede é claramente associada ao arquétipo de Ísis enquanto mãe de Hórus. Joquebede é a mãe que gera, esconde, amamenta e educa Moisés como um filho de Israel para defender o povo contra o Faraó egípcio, opressor de seus pais (Êxodo 2.1-10). E o rio Nilo, que antes era lugar de morte para os primogênitos israelitas (Êxodo 1.22), se transforma em um lugar de esperança para uma nova vida (Êxodo 2.3). Miriã, a irmã de Moisés que conduz toda a trama, é uma referência direta à deusa Hator, pela sua associação à música e à profecia (Êxodo 15.20), bem como ao seu papel de irmã e consorte de Hórus.

Na partida para o Êxodo, na ceia pascal (seder) bem como nas comemorações das festas dos pães asmos, temos a presença e atuação, ainda que oculta no texto, das mulheres no preparo dos alimentos. Da mesma forma podemos intuir que foram as mulheres que mais se alegraram pela preservação de seus filhos quando o Senhor passou sobre suas casas marcadas com o sangue do cordeiro, enquanto que o choro das mães egípcias se ouviu por toda a terra (Êxodo 12.30).

No livro de Cântico dos Cânticos é durante a primavera que os amantes se encontram (Cantares 2.11-12). Da mesma forma é durante o 
mesmo período que Davi se deita pela primeira vez com Bate-seba (2 Samuel 11.1). Dois textos que nos remetem para um jogo de desejo e sedução aproximando-os dos mitos de hierogamias como os de Inanna, Isis e Perséfone relatados acima. O livro bíblico de Cantares é um cântico nupcial, gênero literário muito presente no Oriente Próximo e no Egito antigo. Na poesia amorosa do antigo Egito encontramos relações de incrível proximidade nas expressões e nas situações relatadas em Cantares (Michael FOX, 1985). Diversas imagens de animais e vegetais que dialogam com os corpos dos amantes numa profusão de aromas e cores que são revelados nas traduções dos textos das óstracas. As tradução da Óstraca do Cairo 25218 e Óstraca Deir el-Medina 1266 feitas por Luís Manuel de Araújo (2000, p. 290), por exemplo, revelam uma imagem que poderia ter saído do livro de Cantares:

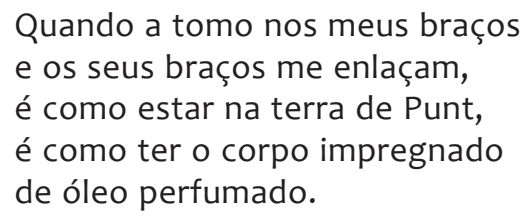

Como comparação, observe-se a semelhança na construção e nos elementos simbólicos deste trecho de Cantares: "Beija-me com os beijos de tua boca; porque melhor é o teu amor do que o vinho. Suave é o aroma de teus unguentos, como óleo derramado é o teu nome." (Cantares 1.2-3). Teodoro de Mopsuéstia (350-428) descreveu o livro de Cantares como sendo uma encenação literária do casamento entre o rei Salomão e a filha de Faraó, o que explicaria a sua grande semelhança com os textos de amor egípcios ${ }^{2}$. Cantares seria, portanto, uma descrição muito próxima à de uma hierogamia sagrada³, onde um casamento divino garante a manutenção da ordem dos ciclos da natureza.

Da mesma forma podemos entender a relação sexual entre Davi e Bate-seba como um mito hierogâmico indutor da fertilidade na história de Israel. Enquanto Bate-seba. estava casada com Urias, não houve o

Comentário introdutório da Bíblia Sagrada, Difusora Bíblica, 2015, p. 1050.

Cabe aqui relembrar também que o livro de cantares foi interpretado tradicionalmente como uma alegoria do relacionamento hierogâmico entre Deus e Israel ou entre Cristo e a Igreja. 
nascimento de filhos numa associação simbólica ao outono-inverno. Após unir-se a Davi, Bate-seba será fértil, associando esta união à primavera-verão. Como no mito de Perséfone, Davi, após o sequestro de Bate-seba, a devolve ao marido Urias e, depois, novamente a retoma para o seu palácio. Bate-seba, como Perséfone, ficará dividida entre o amor de Urias e de Davi e precisará vivenciar o luto antes de se tornar instrumento pleno de vida e fertilidade (2 Samuel 11.26-27). A semente de Davi, plantada no ventre infértil da "mulher de Urias" brotará, mas terá vida curta (2 Samuel 12.15). O primeiro filho de Bate-seba e Davi ocorre em um momento de transição, quando esta ainda está ligada a Urias (ela é referida como "mulher de Urias") e, portanto, embora chegue a nascer, tem vida fugaz. Será o segundo filho nascido desta união que construirá o primeiro templo judaico e será o antecessor do Messias. Com a morte de seu irmão Adonias, Salomão, filho de Davi e Bate-seba, se tornará o único sucessor capaz de manter a linhagem pura da tribo de Judá (Edmund LEACH, 1983).

\begin{tabular}{|c|c|}
\hline Perséfone & Bate-seba \\
\hline união com Hermes $\rightarrow$ fertilidade & união com Urias $\rightarrow$ infertilidade \\
\hline \multicolumn{2}{|c|}{ S E Q U E S T R O } \\
\hline união com Hades $\rightarrow$ infertilidade & união com Davi $\rightarrow$ fertilidade \\
\hline
\end{tabular}

Figura 1: Oposição binária e inversões nos mitos de Perséfone e Bate-seba

Podemos perceber (figura 1) a oposição binária e as inversões entre os mitos de Perséfone e Bate-seba. O sequestro de uma mulher, que seria visto como algo negativo, na história bíblica se torna positivo por favorecer uma união endogâmica que gerará um filho de sangue puro da tribo de Judá. Sendo a união entre Urias e Bate-seba uma união exogâmica ${ }^{4}$ (Urias é Heteu), seu resultado é a infertilidade. A união endogâmica posterior de Bate-seba com Davi, ao contrário, é abençoada por Deus e garante a continuidade da linhagem messiânica (figura 2).

4 Em diversas ocasiões no Antigo Testamento, a Exogamia (casar-se fora do grupo de parentesco) é censurada e a Endogamia (casar-se dentro da mesma parentela) é aconselhada como forma de preservar a possessão da terra dentro da mesma tribo de Israel. 


\begin{tabular}{|c|c|c|c|}
\hline $\begin{array}{c}\text { Perséfone com } \\
\text { Hermes }\end{array}$ & Fertilidade & Bate-seba com Urias & Infertilidade \\
\hline \multicolumn{4}{|c|}{ S E Q U E S T R O } \\
\hline $\begin{array}{c}\text { Perséfone com } \\
\text { Hades }\end{array}$ & Infertilidade & Bate-seba com Davi & $\begin{array}{c}\text { Fertilidade: } \\
\text { concepção de } \\
\text { um filho }\end{array}$ \\
\hline \multicolumn{4}{|c|}{ D E V O L U Ç $\tilde{A} O$} \\
\hline $\begin{array}{c}\text { Perséfone com } \\
\text { Hermes }\end{array}$ & Fertilidade & Bate-seba com Urias & $\begin{array}{l}\text { Infertilidade: } \\
\text { morte de um filho }\end{array}$ \\
\hline \multicolumn{4}{|c|}{ R E TOMA } \\
\hline $\begin{array}{c}\text { Perséfone com } \\
\text { Hades }\end{array}$ & Infertilidade & Bate-seba com Davi & $\begin{array}{c}\text { Fertilidade: } \\
\text { concepção de um } \\
\text { filho }\end{array}$ \\
\hline
\end{tabular}

Figura 2: Leitura sincrônica dos mitos de Perséfone e de Bateseba

Enquanto que no mito de Perséfone, esta fica sempre se dividindo durante o ano entre os dois amantes para manter o equilíbrio das estações do ano, Bate-seba só fará o ciclo de vida e morte uma única vez, pois com a morte de Urias, passará a viver somente com Davi, garantindo a perpetuidade da primavera de fertilidade para Israel.

\section{O SAGRADO FEMININO E A PRIMAVERA NA CONCEPÇÃO E NASCI- MENTO DE JESUS CRISTO}

Se Cantares é também um relato de uma hierogamia entre Salomão e a filha do Faraó, acontecendo na primavera, será esta união fertilizadora que favorecerá o crescimento do povo escolhido por Deus de onde nascerá o Messias de Israel, a derradeira primavera de Deus. O cântico profético de Zacarias (Lucas 1.78), tio de Jesus, já apontava para seu nascimento simbólico na primavera e como sinal da chegada de nova vida ao mundo. O termo, anatolé, pode ser traduzido tanto como "sol nascente", "aurora", "leste" (local do nascer do Sol), ou "broto de uma planta” (STRONG'S EXHAUSTIVE CONCORDANCE), que se relaciona diretamente ao broto do tronco de Jessé5 (Isaias 11.1). A Bíblia na versão

\footnotetext{
“Do tronco de Jessé sairá um rebento, e de suas raízes, um renovo.” Isaías 11.1
} 
King James trará a seguinte tradução: "whereby the dayspring 6 from on high hath visited us." Jesus é anunciado como aquele que virá como o Sol nascente, como o broto do tronco de Jessé, no início de uma nova estação: a primavera de Deus! A profecia se cumpre no nascimento de Jesus durante o recenseamento, praticado no período da primavera para facilitar o deslocamento das pessoas até sua cidade natal. Outro elemento que aponta para isso é o relato do evangelista Lucas sobre os pastores com os rebanhos à noite no campo (Lucas 2.8), fato que não faria sentido em outra estação do ano. A tradição, como Epifânio ressaltou em 214 d.C., aponta a concepção de Jesus na primavera e seu nascimento em meados do inverno (Rogério MOURÃO, 1997). Independentemente da data precisa destes dois acontecimentos, estes são marcados pela primavera!

A concepção de Jesus ocorreu em como uma hierogamia sagrada, quando Maria tomada pelo Espírito Santo é envolta pelo abraço do Deus-Pai. A expressão usada para Espírito Santo em Lucas 1.35 remete para o Espírito de Gênesis 1.2. A concepção de Jesus relatada no evangelho de Lucas se assemelha muito às hierogamias da mitologia antiga. Aqui temos a figura feminina do Espírito Santo materializada no corpo de Maria. A forma gramatical utilizada para Espírito no Antigo Testamento é feminina, pois no hebraico a palavra ruah tem gênero feminino enquanto que o termo usado no grego do Novo Testamento, pneuma, é neutro. Os antigos israelitas compreendiam que, sendo o Espírito gramaticalmente feminino, isto teria implicações em suas funções e características. Assim, o Espírito seria relacionado com a vida, nascimento e crescimento, características associadas à mulher.

Efetivamente, o termo ruah de Gn 1.2 sugere a imagem dum pássaro gigante feminino, chocando o ovo místico cósmico, como origem da vida sobre a terra. [...] O Novo Testamento sempre considerou o Espírito como mãe, responsável pela vida nova e divina. É Ele quem se serve da carne de Maria para gerar humanamente o Filho eterno do Pai, o Homem novo que é Jesus (Herculano ALVES, 1994, p. 60).

A imagem do pássaro feminino que sobrevoa tanto a Terra infértil como a virgem, fecundando-as, nos remete novamente ao mito de Ísis e

6 Dayspring pode ser traduzido como o início de uma nova era ou nova ordem de eventos. Fonte: https://www.merriam-webster.com/dictionary/dayspring acesso em 11/04/2021 
Osíris, pois segundo este, Ísis sobrevoa o corpo reconstituído de Osíris para ser por ele fecundada. O ruach feminino de Gênesis 1.2 e o pneuma de gênero neutro de Lucas 1.35 indicam o mesmo espírito fecundante em forma de sopro de vida.

Em Maria, através do Espírito Santo, o Deus Pai inicia sua obra de redenção da humanidade: "O povo que jazia em trevas viu grande luz, aos que viviam na região da sombra da morte resplandeceu-lhes a luz." (Mateus 4.16, Isaías 9.2) As trevas e a morte do grande inverno em que a humanidade havia estado desde a expulsão do paraíso estavam prestes a findar. O Sol nascente, o broto primaveril de Deus nasceria do solo/ventre de uma mulher. Mais uma vez, o arquétipo do sagrado feminino se mostraria presente no imaginário não só do povo de Israel, mas de toda a humanidade.

Autores como Júlio Chiavenato (2002) apontam para uma correlação simbólica entre a devoção a Maria e a crença mitológica na Grande-Mãe, tendo esta sido assimilada pelos cristãos primitivos como a Virgem Maria. Nas regiões do antigo império romano restam indícios desta correlação. José Leite de Vasconcelos (1988) e Moisés Espirito Santo (1988) relacionaram algumas destas nas suas obras, respectivamente "Religiões da Lusitânia" e "Origens Orientais da Religião Portuguesa". Patrícia CarvaIhinhos (2005, p. 165) considera que "a figura de Maria é um símbolo ou um arquétipo da Grande-Mãe ou das antigas divindades pagãs" e aponta para a possibilidade da valorização de Maria ser uma "manobra de sucesso por parte da Igreja Católica para consolidar seu poder no Império Romano através da criação de um símbolo feminino divino".

O Primeiro Concílio de Éfeso, realizado em 431 d.C. na Igreja de Maria na Ásia Menor discorreu, dentre outros assuntos, sobre a virgindade de Maria: "Se alguém não confessar que o Emanuel é verdadeiro Deus e que, portanto, a Santa Virgem é Theotókos, portanto deu à luz, segundo a carne, ao Verbo de Deus feito carne, seja anátema" (Henry BETTENSON, 1998, p. 93). Lembrando que Éfeso era o local do grande templo da deusa Diana ou Ártemis7, conta a história que o povo, durante o Concílio de Éfeso, teria se reunido ao redor da igreja onde a reunião acontecia e passou a clamar em alta voz: "A Deusa, a Deusa, certamente ela é a Deu-

Ártemis ou Diana, irmã de Apolo, era conhecida como a deusa virgem. Mas para Campbell, Ártemis era uma deusa em sua totalidade, a que dá a vida e a nutre. "Ártemis is the giver of abundance: Our Lady of the Wild Things, and the All-Mother of the many breasts, who bears the totality of the entities of the natural world." (Joseph CAMPBELL, 2013, pos. 2296). 
sa" (Joseph CAMPBELL, 1990, p. 190). Embora a doutrina da Imaculada Conceição só tenha sido promulgada oficialmente em 1854 pelo Papa Pio IX, desde o século IV já haviam escritos relacionados e festas celebradas a este epíteto (Theotókos) de Maria. O dogma da virgindade perpétua de Maria enfatizou sua característica de mãe virgem, relacionada à Deusa-Mãe-Terra, que concebe os seres por partenogênese, além de criar um elo de ligação desta à deusa virgem Diana/Ártemis.

Substituindo as deusas da Lua, a Virgem Maria recebeu também o epíteto de "Lua da Igreja" ou "a que possui a sabedoria perfeita". Consequentemente, em sua invocação como Nossa Senhora da Conceição é retratada grávida e tendo a seus pés uma lua crescente. Sua imagem reflete o texto bíblico de Apocalipse 12.1-2, onde há o relato da batalha final entre a descendência da mulher e a serpente, prometida em Gênesis 3.15. A lua crescente sob seus pés cria uma associação simbólica direta às deusas Ártemis e Ísis facilitando o sincretismo e a absorção do cristianismo pelos povos pagãos. A deusa Ártemis é comumente retratada segurando uma lua crescente (o arco) ou tendo-a sobre a cabeça; é deusa da lua, da caça, dos animais selvagens, do parto e da virgindade na mitologia grega. A lua crescente foi considerada também um atributo da deusa Ísis pelos gregos e romanos.

Reginald Witt (1997) propõe que Ísis teria sido a "grande precursora" de Maria. Para este autor os antigos devotos de Ísis, ao se converterem ao cristianismo, tendiam a ver em Maria características de sua deusa Ísis, pois ambas teriam várias esferas de influência em comum, como a agricultura e a proteção dos marinheiros. Compara também o título "Mãe de Deus" recebido por Maria com o título de "mãe do deus" recebido por Ísis, além do "Nossa Senhora Rainha” de Maria com o "Rainha do Céu"8 de Ísis.

Já o historiador Stephen Benko (1993) usa um argumento semelhante para o surgimento da veneração a Maria, defendendo, porém, que sua adoração tem base na fusão de diversas deusas pagãs e não apenas em Ísis. Da mesma forma, o historiador e religioso John McGuckin (2008) acredita que Maria absorveu traços superficiais dessas deusas em sua iconografia. As Imagens de Ísis com Hórus no colo parecem ter inspirado

Título também dado a Innana/Ishtar (Jeremias 44.17). 
a iconografia de Maria, especialmente as imagens das Virgens do Leite, já que ilustrações de mulheres amamentando eram raras no antigo mundo mediterrâneo fora do Egito (Sharon HEYOB, 1975). Outros/as pesquisadores/as como Sabrina Higgins (2012) e Aline Silveira, Rodolpho Bastos e Janaina Zdebskyi (2018) concordam que tais similaridades indicam que as imagens de Ísis tenham influenciado a concepção das imagens de Maria. Para Elizabeth Bolman (2005) as imagens de Maria amamentando Jesus tinham a clara intenção de apontar para a sua divindade, assim como as imagens de outras deusas amamentando na iconografia egípcia. A associação da imagem da Virgem Maria com o menino Jesus ao colo às pinturas e estátuas de Ísis com Hórus, ambas sentadas em um trono, relaciona-as à posição divina, assim como a presença do filho ao colo e ao seio aponta para características ancestrais do sagrado feminino: maternidade, cuidado, proteção, nutrição e vida.

\section{O SAGRADO FEMININO E A PRIMAVERA NA VIDA DE JESUS CRISTO}

Os quatro evangelhos no Novo Testamento destacam a presença de mulheres durante a formação e atuação de Jesus em seu breve ministério terreno. Desde sua concepção, sua vida esteve ligada às mulheres: sua mãe Maria, sua tia Isabel e a profetisa Ana. Embora tenha vivido em um período e uma sociedade patriarcal, Jesus demonstrou uma relação especial para com as mulheres durante toda a sua vida. Jesus revelou grande coragem quando ignorou as barreiras sociais existentes e exerceu um ministério vital e pessoal junto a essas mulheres (William COLLEMAN, 1991, p.95). Tendo sido criado no judaísmo sabia as regras sociais impostas às mulheres sob a influência grega e romana. Mas, apesar disso Jesus desafiou a sociedade de sua época com atitudes muitas vezes escandalosas para a sociedade da época (algumas até para a nossa sociedade atual), mas que para ele eram naturais, frutos de seu amor e compaixão pela humanidade como um todo.

As referências à primavera são uma constante em seus ensinamentos, com parábolas voltadas muitas vezes a temas agrícolas e femininos. Mas é nos últimos dias de sua vida que a primavera novamente marcaria profundamente a história de Jesus Cristo. Embora a última páscoa de Jesus tenha se iniciado com uma refeição (séder) junto aos seus doze 
companheiros/discípulos homens, sua prisão, julgamento, condenação e morte foram acompanhadas de perto por mulheres que o seguiam (Mateus 27.55-56,61).

Poucos dias antes de sua morte, Jesus separou os doze discípulos à parte e explicou claramente o que aconteceria após sua entrada em Jerusalém (Marcos 10.32-34), mas não foram os doze que compreenderam sua mensagem e sim algumas mulheres que $O$ seguiam e serviam. Antes da entrada triunfal em Jerusalém, Jesus foi até Betânia, cidade em que se sentia acolhido e amado pelos irmãos Maria, Marta e Lázaro. Conhecendo de antemão o sofrimento pelo qual em breve passaria, Jesus buscou o conforto junto aos/às amigos/as. E é em Betânia que será ungido duas vezes por mulheres. O primeiro relato é da unção realizada por Maria enquanto sua irmã Marta servia a ceia a Jesus, a Lázaro e aos discípulos. Maria se aproximou com cerca de meio litro de um perfume valioso e, ao invés de entregá-lo como oferta ao tesoureiro do grupo, Judas, abriu o frasco e derramou-o sobre os pés do Mestre, enxugando-os com seus cabelos (João 12.1-8). Um relato paralelo ocorre em Mateus (26.6-13) e em Marcos (14.3-9), mas desta vez, na quarta-feira da semana santa, em casa de Simão, o leproso, também em Betânia. Dessa vez, a mulher é anônima, mas seu amor por Jesus é tão caro e forte como o de Maria e se materializa na unção da cabeça de Jesus com um perfume. Um ato de amor e honra, mas também de fé na mensagem de Jesus como o Messias. A unção pelas mulheres revela como estas compreenderam que a missão de Jesus estava próxima de ser completada (João 12.7; Mateus 26.12; Marcos 8-9). Temos aqui a presença de três mulheres: Marta, Maria e uma mulher anônima que atuam como em um ritual ancestral de fertilidade, com oferendas de alimentos e bálsamos, antecipando o sacrifício de Cristo, que conduziria à chegada do novo tempo de fertilidade e vida ao mundo.

Na noite da quinta-feira da semana santa, novamente três mulheres se destacam nos dias finais de Jesus segundo o evangelista Mateus. São elas as duas criadas na casa de Caifás (Mateus 26.69-71) e a mulher de Pôncio Pilatos (Mateus 27.19). Nessa noite Jesus fora preso no Getsêmani e levado pelos soldados ao sumo sacerdote Caifás, que junto com os sacerdotes e todo o sinédrio procuraram formas de justificar 
sua condenação. Todos os discípulos haviam fugido (Mateus 26.56), exceto Pedro que seguiu Jesus de longe (Mateus 26.58). Pedro, cujo nome significa "rocha" havia sido avisado por Jesus de que em breve seria abalado e negaria o Cristo por três vezes (Mateus 26.34-35). Embora durante a prisão de Jesus Pedro tenha se mostrado firme em sua defesa (João 18.10), fazendo uso da espada, poucas horas depois se deixa intimidar diante de duas mulheres, duas criadas, e nega Jesus três vezes. Duas mulheres anônimas e invisíveis, apenas duas criadas de Caifás, mas que revelam a fragilidade da humanidade de uma rocha, Pedro. Outra mulher ainda será mencionada como tendo um importante papel nessa mesma noite: a esposa anônima de Pilatos, que a tradição identifica como Cláudia Prócula9 . O evangelista Mateus (27.19) é o único a mencioná-la e ao sonho ${ }^{10}$ que a moveu a tentar impedir a condenação de Jesus por Pilatos. Enquanto o dia anterior é marcado por três muIheres que realizam oferendas simbólicas pela proximidade do sacrifício da divindade na primavera, a quinta-feira é marcada por três mulheres que fazem denúncias provocativas a reações de homens-chave nesse momento da história: Pedro e Pilatos. Na história destas três mulheres podemos perceber traços da denúncia de Inanna/Ishtar a Damuzi/Tamuz, condenando-o por suas ações de insensibilidade.

Jesus é espancado, humilhado e enviado para a morte na sexta-feira. Forçado a carregar uma cruz sobre os ombros machucados em carne viva e sangue, Jesus precisa ainda percorrer um longo caminho do pretório ao calvário. Os doze discípulos, companhia constante nos três anos de ministério, amedrontados, esconderam-se. Mas as discípulas, mulheres invisíveis para a cultura patriarcal do seu tempo, que seguiram,

9 No livro apócrifo do século $V$ "Evangelho de Nicodemus" também chamado de "Atos de Pilatos", a esposa de Pilatos, denominada Prócula envia um mensageiro ao esposo com uma carta. Prócula é descrita como uma mulher piedosa e judia convertida ao cristianismo. O nome Cláudia aparece nos escritos de São Jerônimo (347 - 430 d.C.).

10 O texto apócrifo do Evangelho de Nicodemus (Bart EHRMAN, 2011, p. 419-464) relata que seu sonho foi atribuído pelos judeus a artes de feitiçaria de Jesus. Alguns teólogos da Idade Média como Rabanus Maurus, Bernardo de Clairvaux e Martinho Lutero interpertaram o sonho de Cláudia como uma artimanha diabólica para evitar a consumação do plano de salvação da humanidade. Já Agostinho, Jerônimo e João Calvino acreditavam que o sonho teria origem divina. (Erich Fascher, 1951) 
serviram e aprenderam de Jesus por três anos de suas vidas (Mateus 27.55-56, Marcos 15.40-41) mantiveram-se sempre próximas. Durante a via-crucis, as mulheres "batiam no peito e o lamentavam" (Lucas 23.27). Vendo-as, Jesus com amor diz: "Filhas de Jerusalém, não choreis por mim; chorai antes, por vós mesmas e por vossos filhos!" (Lucas 23.28) O texto de Zacarias (12.10) é tido como profético deste momento da vida de Jesus: “... derramarei o meu espírito de graça e de súplicas; olharão para aquele a quem transpassaram; pranteá-lo-ão como quem pranteia por um unigênito e chorarão por ele como se chora amargamente pelo primogênito." A cena de lamento protagonizada por essas mulheres anônimas remete-nos ao lamento por Damuzi/Tamuz (Ezequiel 8.14) e pela divindade relacionada à fertilidade, Hadade-Rimon ${ }^{11}$, registrado no mesmo texto do profeta Zacarias (12.11): "Naquele dia, será grande o pranto em Jerusalém, como o pranto de Hadade-Rimom, no vale de Megido". Podemos aqui fazer duas importantes associações simbólicas: o pranto das mulheres, que antecipa a ressurreição da divindade na primavera, e a presença do "espírito de graças e de súplicas", que representa a presença da ruach, a face feminina de Deus movendo a ação das mulheres (Zacarias 12.11).

Na narrativa de três dos evangelistas, embora seus nomes variem, registra-se sempre a presença de mulheres ao pé da cruz. Os dois primeiros evangelhos nomeiam três mulheres, enquanto o evangelho de João nomeia quatro mulheres. Mateus (27.56) cita "Maria Madalena, Maria mãe de Tiago e de José e a mulher de Zebedeu". Marcos (15.40) registra a presença de "Maria Madalena, Maria mãe de Tiago, o menor e de José, e Salomé”. Por fim, João (19.25) relatará: “junto à cruz estavam, a mãe de Jesus e a irmã dela e Maria, mulher de Cleópas e Maria Madalena." Herculano Alves (2015, p.1767, nota de rodapé) levanta a questão da possibilidade de que a exegese do texto de João possa indicar também três mulheres sendo uma única pessoa, "a irmã dela, Maria, mulher de Cleópas". Desta forma, teríamos novamente três mulheres presentes na última sexta-feira da vida de Jesus, registrando a presença constante do feminino em seus últimos momentos. Mais

1 Hadad (em Ugaritico ou Acádio) ou Iškur (em sumério) era tido como o deus da tempestade ou das chuvas entre os Cananaeus e Mesopotâmicos (Alberto Green, 2003). 
uma vez são as mulheres que velam nas estações intermediárias entre a morte e a vida, zelando e preparando a terra para a ressurreição da vida. A consequência natural foi tê-las também como testemunhas da primavera de Deus na ressurreição de Jesus.

"Desde a hora sexta até a hora nona, houve trevas sobre toda a terra" (Mateus 27.45) A escuridão que se abateu sobre a terra na sexta-feira quando Jesus morreu, anunciou a proximidade do final do inverno simbólico para a humanidade, pois no domingo a luz divina iluminou o túmulo e Jesus ressuscitou inaugurando uma nova era, a primavera de Deus para o mundo. Todos os evangelistas registraram a presença de mulheres no momento da ressurreição de Cristo. Mateus (28.1) relata: "Maria Madalena e a outra Maria foram ver o sepulcro". Marcos (16.1): "Maria Madalena, Maria mãe de Tiago e Salomé compraram aromas para irem embalsamá-lo". Lucas inicialmente não as nomeia e posteriormente as identifica como "Maria Madalena, Joana e Maria mãe de Tiago; também as demais que estavam com elas" (Lucas 24.10), apontando para a presença de mais mulheres do que nos registros dos demais evangelistas. João (20.1) apenas registra que "Maria Madalena foi ao sepulcro de madrugada", mas sua fala no plural ("não sabemos...") no versículo seguinte denuncia a presença de mais mulheres no evento. Dois evangelistas registram três nomes de mulheres, um cita dois nomes e o último, apenas um nome. Embora não haja uma concordância entre os evangelistas sobre a identidade das mulheres que presenciaram a primeira aparição de Jesus após sua ressurreição, um nome é constante: Maria Madalena. Como Ísis, Maria Madalena se encontra inconsolável pela morte do amado e o busca: "... levaram o meu Senhor, e não sei onde o puseram." (João 20.13) Jesus lhe aparece ressuscitado, mas Madalena não o reconhece de pronto (João 20.14-15). Semelhantemente a Osíris, Jesus lhe aparece como "pessoa espiritual", embora em corpo físico, este não é mais o corpo físico que Madalena conhecera e sim um corpo espiritual. Paulo, em seu estudo sobre os corpos ressuscitados, registrará: "Semeia-se corpo natural, ressuscita corpo espiritual" ( 1 Coríntios 15.44). Jesus ressuscitado na primavera inaugura um novo tempo para a humanidade. Essa será a missão de Maria Madalena: semear na Terra a mensagem de uma nova relação entre Deus e aqueles/as que, a partir de então, serão seus/suas filho/as muito amados/as (João 20.17).

Completando a correlação mítica com as divindades pascais, Cristo realiza a sua descida ao mundo subterrâneo (Efésios 4.9-10; 1 Pedro 3.19, 
4.6), reino de Hades, de onde é trazido de volta por Deus-Pai (Atos 2.24, 32). A dimensão cósmica deste mistério pascal associa-se aos mitos de Inanna e Perséfone, quando a primeira, pela sua própria vontade, e a segunda, pela vontade de Hades, descem ao mundo subterrâneo, sendo resgatadas de lá, Inanna por seu pai e Perséfone por sua mãe. Os três dias em que Inanna permaneceu como morta no mundo subterrâneo são correlatos diretos aos três dias entre a morte e ressurreição de Jesus (Mateus 16.21, 17.23, 20.19; Lucas 9.22, 18.33, 24.7 e 46).

A presença dos elementos míticos relacionados à vida de Jesus bem como a presença feminina e as referências à primavera são uma constante (figura 3 ).

\begin{tabular}{|c|c|c|c|c|c|c|}
\hline estação & Evento & desenvolvimento & $\begin{array}{l}\text { Título de } \\
\text { Jesus }\end{array}$ & $\begin{array}{l}\text { Texto } \\
\text { bíblico }\end{array}$ & $\begin{array}{l}\text { Personagem } \\
\text { feminino }\end{array}$ & $\begin{array}{l}\text { Perso- } \\
\text { nagem } \\
\text { mítico }\end{array}$ \\
\hline \multirow[t]{3}{*}{ Primavera/Verão } & $\begin{array}{l}\text { Concepção/nasci- } \\
\text { mento }\end{array}$ & formação & Filho de Deus & Lucas 1.35 & $\begin{array}{l}\text { Maria, Isa- } \\
\text { bel e Ana }\end{array}$ & $\begin{array}{l}\text { Ísis e } \\
\text { Hórus }\end{array}$ \\
\hline & Ministério terreno & $\begin{array}{c}\text { Ensino/formação } \\
\text { de discípulos }\end{array}$ & Rabi/Mestre & João 20.16 & $\begin{array}{c}\text { Madalena } \\
\text { e outras } \\
\text { mulheres }\end{array}$ & --- \\
\hline & $\begin{array}{c}\text { Preparação para o } \\
\text { sacrifício }\end{array}$ & Unção e oferendas & $\begin{array}{l}\text { Cristo } \\
\text { (ungido) }\end{array}$ & João 11.27 & $\begin{array}{l}\text { Marta, Ma- } \\
\text { ria e mulher } \\
\text { anônima }\end{array}$ & --- \\
\hline \multirow[t]{2}{*}{ Outono/Inverno } & Prisão e condenação & $\begin{array}{l}\text { Denúncia de } \\
\text { iniquidade }\end{array}$ & $\begin{array}{l}\text { Cordeiro } \\
\text { (sacrifício) }\end{array}$ & João 1.29 & $\begin{array}{l}\text { Criadas de } \\
\text { Caifás e } \\
\text { esposa de } \\
\text { Pilatos }\end{array}$ & Inanna \\
\hline & $\begin{array}{l}\text { Morte e descida ao } \\
\text { mundo dos mortos }\end{array}$ & Lamentos & $\begin{array}{l}\text { Messias } \\
\text { (rei de paz) }\end{array}$ & $\begin{array}{c}\text { João } \\
4.25-26\end{array}$ & $\begin{array}{c}\text { Mulheres } \\
\text { de Jerusa- } \\
\text { lém, Maria, } \\
\text { Madalena } \\
\text { e outras } \\
\text { mulheres }\end{array}$ & $\begin{array}{l}\text { Innana e } \\
\text { Perséfone }\end{array}$ \\
\hline Primavera/Verão & Ressurreição & testemunho & Vida & João 11.25 & Madalena & Ísis e Osíris \\
\hline
\end{tabular}

Figura 3: O ciclo da primavera na vida de Jesus Cristo

Jesus iniciou e terminou a sua vida terrena na primavera e, assim como ocorreu com Bate-seba, só repetiu o ciclo uma única vez: "assim também Cristo, tendo-se oferecido uma vez para sempre para tirar os pecados de muitos, aparecerá uma segunda vez, sem pecado, aos que o aguardam para a salvação" (Hebreus 9.28). Antes mesmo de sua 
morte e ressurreição Jesus anunciou a seus discípulos e discípulas que uma vez mais um "inverno" de sofrimento, guerras, fome, epidemias e morte se abateria sobre a terra (Lucas 21. 7-28), mas que este também passaria. Jesus voltaria novamente e, com ele, renasceria a esperança e a vida na terra. Para ilustrar sua segunda vinda, Jesus usou de uma parábola comparando seu retorno à primavera: "Vede a figueira e todas as árvores. Quando começam a brotar, vendo-o, sabeis, por vós mesmos, que o verão está próximo. Assim também, quando virdes acontecerem estas coisas, sabei que está próximo o reino de Deus" (Lucas 21.29-31). Se Jesus é a primavera de Deus, sua segunda vinda dará início ao verão do reino de Deus na Terra.

\section{CONSIDERAÇÕES FINAIS}

Uma leitura mais cuidadosa e livre de amarras culturais pode desvendar relações que antes não eram percebidas. Tendo como fio condutor desta leitura a presença do feminino e suas relações com as festas e divindades associadas à primavera, vemos um descortinar de significados inconscientes. A presença e importância das mulheres na Bíblia, e em especial nos assuntos referentes à primavera, remontam à sua imemorial associação à fertilidade e à geração e manutenção da vida. A referência recorrente ao número três nas histórias merece um estudo mais aprofundado. Podemos intuir seu significado de totalidade, pois matematicamente, segundo Pitágoras, seria a soma do um, que significa unidade, e do dois, que significa diversidade. Assim, toda a aparição de três mulheres seria representativa de todo o gênero feminino. São três as mulheres que salvam a vida de Moisés, o libertador que conduzirá o povo da escravidão da morte à vida na liberdade da terra prometida. São três as mulheres que atuarão na infância de Jesus, como são três as mulheres que o preparam para seu sacrifício, alimentando-o e ungindo-o ritualmente. São três as mulheres que se levantam para mostrar o erro dos homens e são três as mulheres junto à cruz de Jesus. Nestas mulheres todo o gênero feminino se sente representado e reconhecido: "Onde for pregado em todo o mundo este evangelho, será também contado o que ela fez, para memória sua." (Mateus 26.13)

A manifestação do Espírito de Deus (ruach) sempre ocorre como que num sobrevoo de uma ave, à semelhança da forma que Isis toma para ser fecundada por Osíris. O Espírito sobrevoa a terra infértil, a virgem e as tristes mulheres de Jerusalém. O tríplice sobrevoo do Espírito concede a vida onde há morte, infertilidade e tristeza (figura 4). 


\begin{tabular}{|l|l|l|l|}
\hline Texto bíblico & Termo original & O espírito paira & resultado \\
\hline Gênesis 1.2 & ruach & Sobre as águas & Cria o mundo \\
\hline Lucas 1.35 & pneuma & Sobre Maria & Cria o filho de Deus \\
\hline Zacarias 12.10 & ruach & $\begin{array}{l}\text { Sobre as mulheres } \\
\text { de Jerusalém }\end{array}$ & $\begin{array}{l}\text { Cria a esperança da } \\
\text { ressurreição }\end{array}$ \\
\hline
\end{tabular}

Figura 4: A tríplice presença do Espírito feminino de Deus

Não podemos esquecer, porém, que o ciclo da vida, com estreita ligação ao sagrado feminino e à primavera, também é trino: nascimento, vida e morte. A trindade das deusas da primavera conhecidas pelo Israel bíblico, Inanna/Ishtar, Ísis e Perséfone vão ter seu correlato entre as mulheres da Bíblia. Bate-seba está para Perséfone como as criadas e a esposa de Pilatos estão para Inanna e Joquebede, Maria e Madalena estão para Ísis. As relações estabelecidas entre os elementos míticos das três deusas primaveris com as histórias bíblicas podem assim ser visualizadas (figura 5).

\begin{tabular}{|l|l|l|}
\hline Mito & Elementos míticos & Personagem bíblico \\
\hline \multirow{4}{*}{ Inanna/Ishtar } & Descida voluntária ao submundo & Jesus \\
\cline { 2 - 3 } & Resgate por Enlil & Deus \\
\cline { 2 - 3 } & $\begin{array}{l}\text { Denúncia das iniquidades de Damuzi/ } \\
\text { Tamuz }\end{array}$ & $\begin{array}{l}\text { Criadas de Caifás e esposa de Pi- } \\
\text { latos }\end{array}$ \\
\hline \multirow{4}{*}{ Ísis } & Busca por Osíris & Maria Madalena \\
\cline { 2 - 3 } & Concepção de Hórus & Maria \\
\cline { 2 - 3 } & Cuidado e proteção de Hórus & Joquebede \\
\hline Perséfone & União com Hermes & Bate-seba e Davi \\
\cline { 2 - 3 } & Sequestro por Hades & Davi \\
\cline { 2 - 3 } & União com Hades & Bate-seba e Urias \\
\cline { 2 - 3 } & Lamento de Deméter & Maria \\
\cline { 2 - 3 } & Resgate por Deméter & Deus \\
\hline
\end{tabular}

Figura 5: Elementos relacionais entre os mitos das deusas da primavera e as histórias bíblicas 
Todas as relações estabelecidas neste estudo nos levam a indícios de que os arquétipos ancestrais do feminino permanecem através dos tempos, ainda que submersos nas tramas de condução narrativa masculina das histórias bíblicas. Os traços fundamentais do sagrado feminino resistem, fazendo frente às diversas tentativas de marginalização e ocultação no texto e nas suas interpretações. Símbolos e signos coletivos que trazemos inconscientemente e que ligam a mulher à fertilidade e à vida e que continuarão a ressuscitar eternamente nos mitos e histórias da humanidade. Os atributos e imagens das deusas primaveris se mantêm numa continuidade que as conecta às personagens bíblicas femininas e mesmo a Jesus como estruturas mentais ancestrais.

As referências à primavera são uma constante na Bíblia como um todo, revelando a compreensão cíclica da natureza bem como a sua relação com a renovação da esperança e da vida. A ressurreição de Jesus inaugura a primavera simbólica para a humanidade e o anúncio de sua segunda vinda traz consigo a promessa da derradeira e última primavera que antecede a chegada do verão eterno com Deus: "Tragada foi a morte (inverno) pela vida (primavera)” (1 Coríntios 15.54).

\section{REFERÊNCIAS BIBLIOGRÁFICAS}

ALVES, Herculano (coord.) Bíblia Sagrada. Fátima: Difusora Bíblica, 2015.

ALVES, Herculano. Deus no feminino no Antigo Testamento. In: MORGADO, José Joaquim Lopes (dir.). A mulher na Bíblia, na Igreja e na sociedade. Revista Bíblica, série científica, Fátima, n. 3, ano II, dezembro, p. 47-68, 1994.

ARAÚJO, Luís Manuel de. Estudos sobre erotismo no antigo Egipto. Lisboa: Colibri, 2000. BENKO, Stephen. The virgin goddess: studies in the pagan and Christian roots of Mariology. Leiden; New York; Köln: E. J. Brill, 1993.

BETTENSON, Henry. Documentos da Igreja cristã. São Paulo: ASTE/Simpósio, 1998.

BOLMAN, Elizabeth. The Enigmatic Coptic Galaktotrophousa and the Cult of the Virgin Mary in Egypt. In: VASSILAKI, Maria. Images of the Mother of God: Perceptions of the Theotokos in Byzantium. [S.I.]: Ashgate Publishing, 2005, pp. 17-18.

BOWKER, John. Deus - uma breve história. São Paulo: Globo, 2002.

CAMPBELL, Joseph. Goddesses: mysteries of the feminine divine. E-book, Stillpoint Digital Press, 2013.

CAMPBELL, Joseph. O Poder do Mito. São Paulo: Palas Athenas, 1990. 
CARVALHINHOS, Patrícia de Jesus. Hierotoponímia Portuguesa - de Leite de Vasconcelos às atuais teorias onomásticas. Estudo de caso: as nossas senhoras. Tese de Doutorado apresentada ao Programa de Pós-Graduação em Semiótica e Linguística Geral do Departamento de Linguística da Faculdade de Filosofia, Letras e Ciências Humanas da Universidade de São Paulo, São Paulo, 2005.

CHIAVENATO, Júlio José. Religião: da origem a ideologia. Ribeirão Preto: Funpec Editora, 2002.

EHRMAN, Bart D. The Apocryphal Gospels: texts and translations. New York : Oxford University Press, 2011.

ELIADE, Mircea. História das crenças e das ideias religiosas vol.1. Rio de Janeiro: Zahar, 2010.

ESPIRITO SANTO, Moisés. Origens orientais da religião portuguesa. Lisboa: Typographia de J.J.A.Silva, 1988.

FASCHER, Erich. "Das” Weib des Pilatus: Matthäus 27,19. Berlim: Niemeyer, 1951.

FOX, Michael V. The Song of Songs and the Ancient Egyptian Love Songs. Wisconsin: University of Wisconsin Press, 1985.

GIMBUTAS, Marija. Os deuses e deusas da Europa Velha, 7000-3500BC. Londres: Tamisa e Hudson, 1974.

GREEN, Alberto R. W. The Storm-God in the Ancient Near East. Winona Lake, Indiana: Eisenbrauns, 2003.

HEIDEL, Alexandrer. The Babylonian Genesis. Chicago/London: University of Chicago Press, 1972.

HESÍODO. Teogonia - a origem dos Deuses. Organização e tradução: Christian Werner. São Paulo.: Editora Hedra, 2013.

HEYOB, Sharon Kelly. The Cult of Isis among Women in the Graeco-Roman World. [S.I.]: Brill, 1975.

HIGGINS, Sabrina. Divine Mothers: The Influence of Isis on the Virgin Mary in Egyptian Lactans-Iconography. Journal of the Canadian Society for Coptic Studies, v. 3, n. 4, 2012, pp. 78-79.

KLETTER, Raz , ZIFFER, Irit Ziffer, ZWICKEL, Wolfgang. Yavneh II -The 'Temple Hill' Repository Pit. Fribourg Switzerland : Academic Press Fribourg, 2015.

LEACH, Edmund. A legitimidade de Salomão. In LEACH, E. Antropologia. São Paulo: Ática, pp. 70-115, 1983.

LEITE DE VASCONCELOS, José. Religiões da Lusitânia. Lisboa: Imprensa Nacional, 1988. MCGUCKIN, John Anthony. The Early Cult of Mary and Inter-Religious Contexts in the Fifth-Century Church. In: MAUNDER, Chris. The Origins of the Cult of the Virgin Mary. [S.I.]: Burns and Oates, 2008, pp. 17-18. 
MOURÃO, Rogério de Freitas. O terceiro milênio já começou. Folha de São Paulo, São Paulo, 2, mar, 1997, Caderno Ciência. Disponível em: <https://www1.folha.uol.com.br/ fsp/ciencia/fe020305.htm>. Acesso em: 05 abr. 2021.

PLUTARCO. Isis y Osiris. Barcelona: Ediciones Obelisco, 2006.

SILVEIRA, Aline Dias da; BASTOS, Rodolpho Alexandre Santos Melo; ZDEBSKYI, Janaina de Fátima. O sagrado feminino entre hebreus e cristãos: das grandes deusas à Maria. Revista de História Comparada, Rio de Janeiro, v. 12, n. 2, 2018, pp. 6-34.

STRONG'S EXHAUSTIVE CONCORDANCE, Disponível em: <https://biblehub.com/greek/395. htm>. Acesso em: 05 abr. 2021.

WITT, Reginald Eldred. Isis in the Ancient World. Baltimore: Johns Hopkins University Press, 1997.

Submetido em: 14-4-2021

Aceito em: 17-5-2021 